\title{
Personal exposure to particle concentration in a busy street
}

\author{
J. Garcia, R. Cerdeira, N. Tavares \& L. M. R. Coelho \\ Escola Superior de Tecnologia de Setúbal, Instituto Politécnico, \\ Setúbal, Portugal
}

\begin{abstract}
Humanity has been discussing aspects like environment, sustainable development, public health, leisure and work. Connections between these aspects are increasing its importance to decision makers. Urban air quality levels are one of the most important items, concerning public health in urban environment. The knowledge of pollutants influence on human health is a matter of major importance nowadays, and it is known that personal exposure to particle concentration is a key factor in citizens' health. Aspects like street geometry, motorways, pedestrian ways, traffic strategies, time and schedules, can influence air quality levels and consequently human exposure.

This paper studies the influence of street geometry, wind direction, daily car traffic, pedestrian trajectories and particle matter concentration $\left(\mathrm{PM}_{10}\right)$ levels in short-term personal exposure on a busy street of Barreiro City in Portugal. Ansys Fluent was used to simulate particle dispersion in Bocage Street. Buildings' height, width, length and geometry, as well as distance between buildings and road width were considered in the simulation work. Different meteorological conditions were simulated, namely, wind direction and wind velocity.

The results show that pollutant concentration is highly dependent on street geometry and wind conditions. The pedestrian trajectories and their time schedules also play a major rule in short-term personal exposure to $\mathrm{PM}_{10}$. It was noticed that when the building's orientation is the same as the wind, good pollutant dispersion is promoted. Also different size in buildings promotes recirculation that can be positive, increasing the wind velocity and promoting pollutant dispersion, if the wind direction is from North, or negative trapping pollutants when the wind is from South. It is also possible to conclude that pedestrian trajectories that correspond to crossing the road in the centre of the
\end{abstract}


street results in the highest values in terms of short-term personal exposure to $\mathrm{PM}_{10}$.

Keywords: $P M_{10}$, personal exposure, street canyon, buildings configuration, fluent.

\section{Introduction}

The importance of achieving good air quality is a key factor in urban planning nowadays. Aspects like traffic, street configuration and buildings' geometry, green spaces and gardens and the pedestrian ways are increasing its importance to decision makers. When speaking about urban air quality, particle concentration is one major issue and modern studies have dedicated particular attention to the influence of street canyon design in the dispersion of pollutants in general and $\mathrm{PM}_{10}$ in particular. Numerical tools like Computational Fluid Dynamics (CFD) models have been highly developed, and are now a very reliable tool for simulating pollutant concentrations in urban areas. Very satisfactory modelling accuracy is now possible, mainly due to the continuous important development of very powerful numerical codes, parallel to fantastic increases in hardware performances. Complementary with these computational tools measurement campaigns are also very important, because they contribute to validate the simulations and help in understanding the accuracy rate of computational results. In the range of air pollutants, particular attention was dedicated to Particulate Matter (PM) considering both $\mathrm{PM}_{10}$ and $\mathrm{PM}_{2,5}[1,2]$ and, more recently, nanoparticles [3]. Most epidemiological studies have focused on $\mathrm{PM}_{10}$ and $\mathrm{PM}_{2,5}$ and there is certain evidence that short term exposure to high concentrations of $\mathrm{PM}_{10}$ can aggravate pulmonary diseases and have an influence on paediatric asthma [4], and long term exposure to high concentrations of $\mathrm{PM}_{10}$ may increase the risk of cardiovascular and pulmonary disease. This article studies the influence of personal exposure to $\mathrm{PM}_{10}$ in a particular street in Barreiro city in Portugal in particular considering different pedestrian ways in that particular street.

\section{The street}

The street that is considered in this study is part of Avenida do Bocage which is located in Barreiro city. Barreiro is a medium size city located $40 \mathrm{~km}$ south of Lisbon (Figure 1). This is a small city, over $34 \mathrm{~km}^{2}$ and 80000 inhabitants, with industry near the centre and typical city traffic. Barreiro is almost flat, with the highest point at approximately 10 meters above sea level. The weather is temperate, with no severe seasons. Avenida do Bocage is an important strategic key point in the city, because it connects the city centre of Barreiro with an important highway from the capital of Portugal, Lisbon. So the traffic flux is very important especially during rush hour, representing the main source of pollution in the street. The importance of this street is also connected with the fact that it has a primary school (Escola Básica $n^{\circ} 5$ ) and with the fact that 


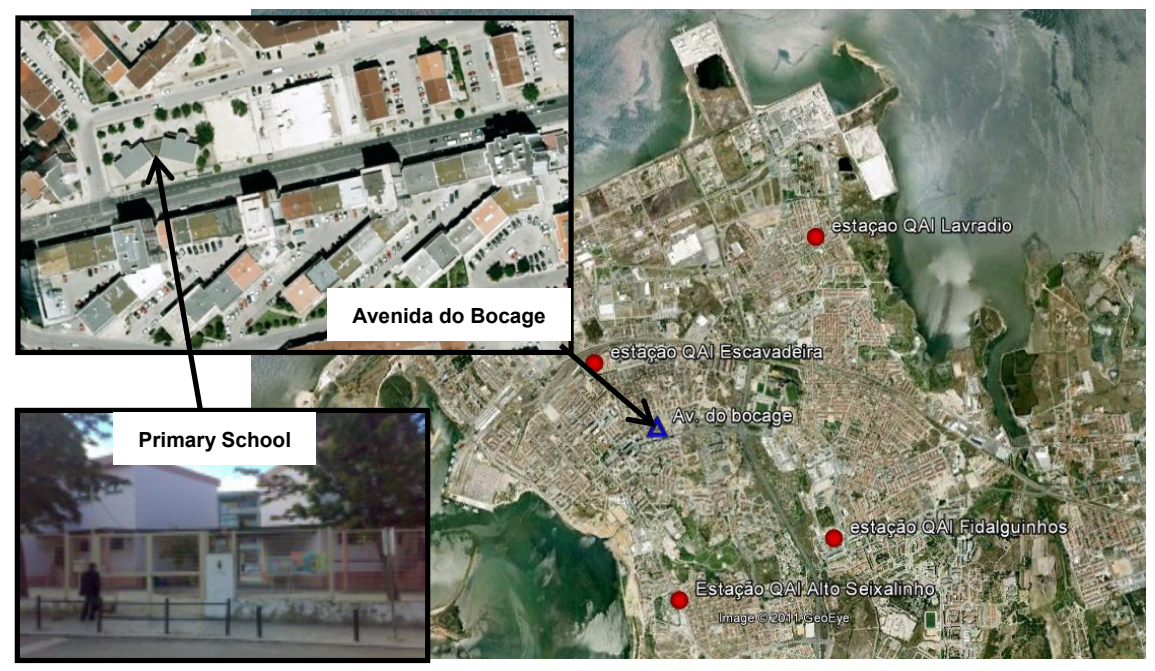

Figure 1: $\quad$ Location of Avenida do Bocage, the studied street.

represents an important pedestrian way for people who go to the river or to the fluvial station.

\section{The CFD simulation}

The CFD simulation was carried out with Ansys Fluent 12.0 software, which is multi-purpose commercial software, widely used in this kind of application and constantly validated through comparison of results with other validated models [5] or through wind tunnel experiences [6]. To fulfil the aim of this study, the spatial discretisation of the computational domain a tetrahedral grid was used, refined near the buildings. The geometry of the street is shown in figure 2 and also the domain regarding wind from the west. As different wind directions were studied, different domains were used, to ensure sufficient distance between the buildings and the domain boundaries in the simulation. A 3D flow simulation with a Lagrangian approach was used, assuming steady state conditions, and for the turbulence, the k-epsilon turbulence model was used, more precisely the RNG k-epsilon turbulence mode providing an analytical formula for turbulent Prandtl numbers and an analytically-derived differential formula for effective viscosity that accounts for low-Reynolds-number effects [7]. A wind profile, turbulent kinetic energy and turbulence dissipation rate was introduced as a user defined function (UDF) considering a power-law vertical wind profile. The 2way street $\mathrm{PM}_{10}$ car emission rate was introduced, using the ADMS-Urban model, and considering the traffic that crosses the street. No chemical reactions were considered for $\mathrm{PM}_{10}$ emissions. In terms of boundary conditions, a no-slip condition was imposed at all solid surfaces (the flow in the near-wall region was represented by the law-of-the-wall for mean velocity), at the top a symmetry 

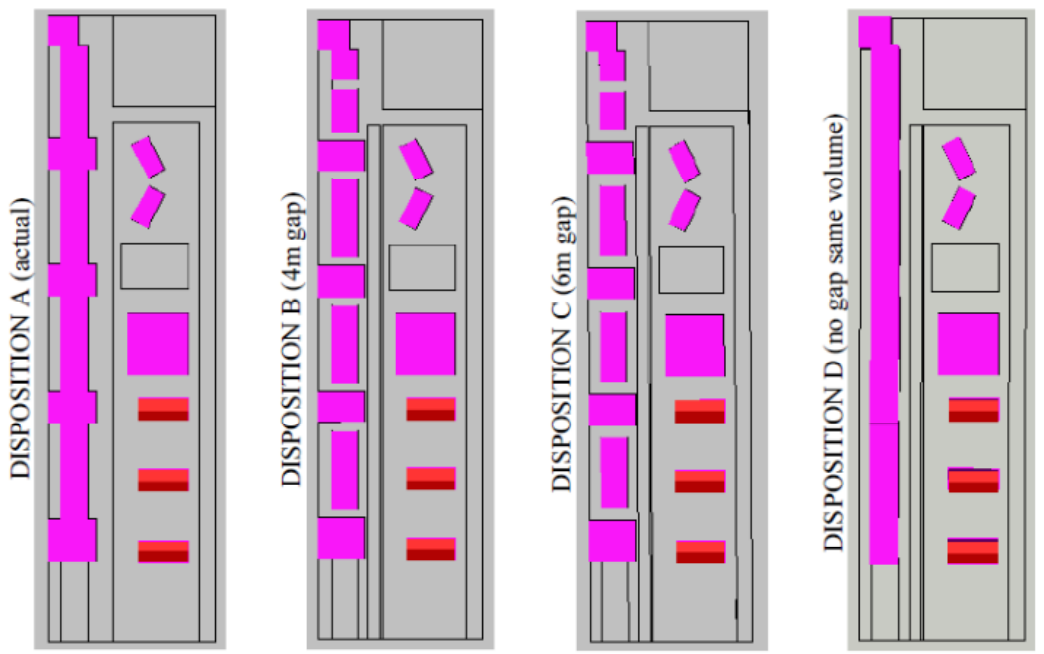

Figure 2: $\quad$ The four building disposition scenarios considered.

boundary was considered, assuming a zero flux of all quantities across the horizontal plane. For this study the simulation domain considered was a $715 \times 300 \mathrm{~m}^{2}$ centred in the Av Bocage with approximately 160,200 cells.

The characterization of the traffic emissions in the domain was made by the implementation of a traffic counting campaign in the street. The counting was carried in periods of one hour and the vehicle characterization was aggregated according to its typical vehicle categories (light duty, heavy duty, buses and motorcycles). $\mathrm{PM}_{10}$ emissions were then calculated by the model ADMS Urban, considering traffic as line sources and considering the mean traffic number of vehicles in rough hours as the baseline scenario for traffic emissions. The other emissions considered in the domain, were introduced as background concentrations in the model, and summed to the Fluent results. The value for background concentrations was collected from the Portuguese Air Quality Stations system. The Fidalguinhos Air Quality station data for $\mathrm{PM}_{10}$ was used, as this station is classified as urban background station. The model validation was made using real measurements of $\mathrm{PM}_{10}$ concentrations made in the street [8].

\section{The four scenarios considered}

Four scenarios to the configuration of Avenida do Bocage were considered, concerning building disposition. One corresponding to the actual geometry of the street with the actual architectural layout, disposition and volumetric configuration of buildings (Disposition A). Three other virtual dispositions for the street buildings were simulated, considering the alteration of the buildings configurations, with the objective of trying to improve the air quality in this street. The first new virtual configuration, designed as Disposition B, considers a 
new gap of $4 \mathrm{~m}$ between the buildings along the street. The scenario designed as Disposition $\mathrm{C}$ was also tried, considering gaps of $6 \mathrm{~m}$ between the buildings along the street. Finally the scenario designed as Disposition D, considerer the same volume as actual real disposition for the buildings along the street, but considers the same high and width for all buildings along the street without gap between buildings. The four building disposition scenarios are shown in figure 2 .

\section{The $\mathrm{PM}_{10}$ concentration results}

The concentration results obtained for $\mathrm{PM}_{10}$ simulations for horizontal concentrations fields to the actual (real) configuration (Disposition A) of the street, considering the four wind directions, are presented in figure 3 . This figure shows contours of $\mathrm{PM}_{10}$ concentrations at $1,5 \mathrm{~m}$ high (considered the medium typical human nose level and used in frequent exposure studies) considering only traffic emissions (no background concentrations).

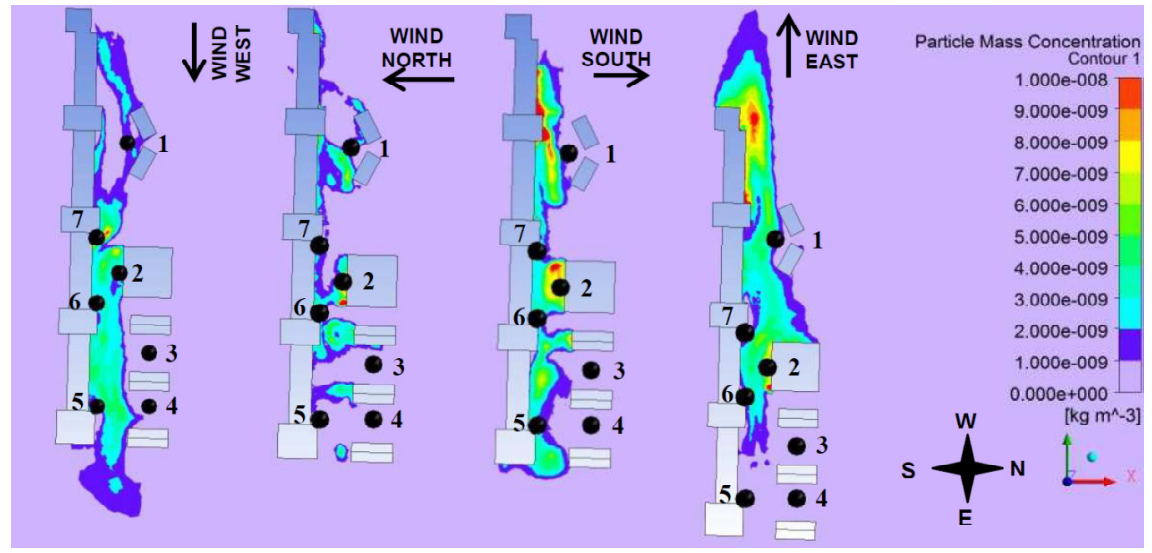

Figure 3: Contour plots of $\mathrm{PM}_{10}$ concentrations at $1.5 \mathrm{~m}$ level for the actual street configuration (Disposition A) for the main four wind directions.

In table 1 are shown the values of $\mathrm{PM}_{10}$ simulated concentrations at $1.5 \mathrm{~m}$ high considering all the emissions (traffic + background) for the actual (real) configuration of the street (Disposition A). These concentrations are shown for seven strategic points located in the street. Additionally it is also shown the mean concentration value for a plane located $1,5 \mathrm{~m}$ high and also for the mean concentration at $1.5 \mathrm{~m}$ high weighted by the wind frequency, this value is designed by $\mathrm{CW}$ (Weighted Concentration).

$$
C W=C P M_{10} \times f i
$$

where $C P M_{10}$ is the concentration of $\mathrm{PM}_{10}\left(\mu \mathrm{g} / \mathrm{m}^{3}\right)$ and $f i$ is the wind direction frequency. 
Table 1: $\quad \mathrm{PM}_{10}$ concentrations at $1.5 \mathrm{~m}$ high for disposition A (actual real configuration).

\begin{tabular}{|c|c|c|c|c|c|c|}
\hline Designation & Location & $\begin{array}{c}\text { PM }_{10} \text { Conc. } \\
\left(\mu \mathrm{g} / \mathrm{m}^{3}\right) \\
\text { West wind }\end{array}$ & $\begin{array}{c}\text { PM }_{10} \text { Conc. } \\
\left(\mu \mathrm{g} / \mathrm{m}^{3}\right) \\
\text { North wind }\end{array}$ & $\begin{array}{c}\mathrm{PM}_{10} \text { Conc. } \\
\left(\mu \mathrm{g} / \mathrm{m}^{3}\right) \\
\text { South wind }\end{array}$ & $\begin{array}{c}\mathrm{PM}_{10} \text { Conc. } \\
\left(\mu \mathrm{g} / \mathrm{m}^{3}\right) \\
\text { East wind }\end{array}$ & $\begin{array}{c}C W \\
(\mu \mathrm{g} / \mathrm{m} 3)\end{array}$ \\
\hline Point 1 & School & 21.6 & 21.2 & 20.7 & 22.3 & 21.3 \\
\hline Point 2 & Bingo & 23.0 & 28.6 & 27.1 & 27.0 & 25.4 \\
\hline Point 3 & Car park(border) & 20.1 & 20.0 & 20.1 & 20.0 & 20.1 \\
\hline Point 4 & Car park (middle) & 20.4 & 20.0 & 20.1 & 20.0 & 20.2 \\
\hline Point 5 & High building corner & 20.5 & 20.6 & 22.7 & 20.0 & 20.9 \\
\hline Point 6 & Residential building (east) & 22.2 & 21.5 & 21.9 & 21.0 & 21.7 \\
\hline Point 7 & Resid. building (west) & 25.0 & 20.9 & 22.5 & 20.7 & 22.8 \\
\hline Mean value & $1,5 \mathrm{~m}$ plane (all domain) & 20.8 & 20.5 & 21.0 & 21.1 & ---- \\
\hline $\mathrm{CW}$ & 1,5m plane (all domain) & 20.3 & 20.1 & 20.1 & 20.1 & ---- \\
\hline
\end{tabular}

The simulation results shown that the highest value of $\mathrm{PM}_{10}$ concentration is achieved in point 2 (Bingo building) with a value of $28,6 \mu \mathrm{g} / \mathrm{m}^{3}$ for north wind conditions. However, if we consider the mean value of concentrations at $1,5 \mathrm{~m}$ high plane for the entire domain, the highest value is achieved for east wind conditions with a mean value of $21.1 \mu \mathrm{g} / \mathrm{m}^{3}$.

Results obtained for the simulations with the new configurations are shown in figures 4-6 and in tables 2-4. Figure 4 shows the results obtained for the simulations for $\mathrm{PM}_{10}$ concentrations horizontal fields for Disposition $\mathrm{B}$, which corresponds to having a gap of $4 \mathrm{~m}$ between the buildings along the street. Figure 5 shows the results obtained for the simulations for $\mathrm{PM}_{10}$ concentrations horizontal fields for Disposition $\mathrm{C}$, which corresponds to having a gap of $6 \mathrm{~m}$ between the buildings along the street. Figure 6 shows the results obtained for the simulations for $\mathrm{PM}_{10}$ concentrations horizontal fields for Disposition $\mathrm{D}$, which corresponds to no gap between buildings but considering the same height and width for all buildings. In these figures, contours of $\mathrm{PM}_{10}$ concentrations at $1.5 \mathrm{~m}$ high, considering only traffic emissions (no background concentrations), are shown for the four main wind directions studied. Tables $2-4$ show the values of $\mathrm{PM}_{10}$ simulated concentrations at $1.5 \mathrm{~m}$ high considering all the emissions (traffic + background) for the four scenarios considered, Dispositions A, B, C and D.

By the analysis of figure 4 and table 2, it is visible that the implementation of a $4 \mathrm{~m}$ gap between buildings, generically decreases significantly the concentrations of $\mathrm{PM}_{10}$ in the street. This is due to the fact that these gaps between the buildings reduce the effects of the creation of a vortex inside the street since there is no barrier to the wind, resulting in a better capacity of pollutant dispersion along the street decreasing the $\mathrm{PM}_{10}$ concentrations.

The results of figure 5 and table 3 shows that with the implementation of a $6 \mathrm{~m}$ gap between buildings (disposition $\mathrm{C}$ ) compared to the scenario of having a $4 \mathrm{~m}$ gap between buildings (disposition $\mathrm{B}$ ) does not represent a visible decrease in $\mathrm{PM}_{10}$ concentrations along the street, concluding that increasing gap length does not bring significant improvements in the street air quality. 


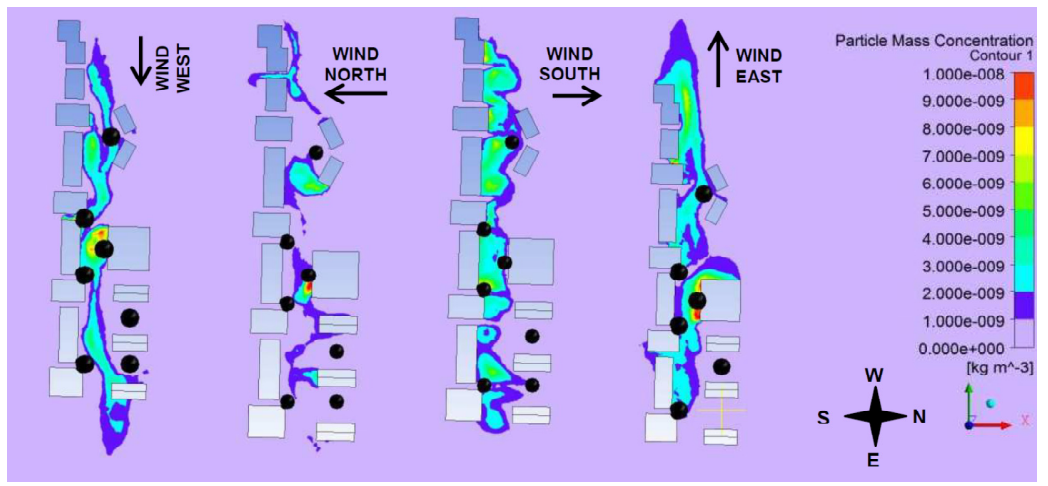

Figure 4: Contour plots of $\mathrm{PM}_{10}$ concentrations at $1.5 \mathrm{~m}$ level for disposition $\mathrm{B}$ (4m gap) for the main four wind directions.

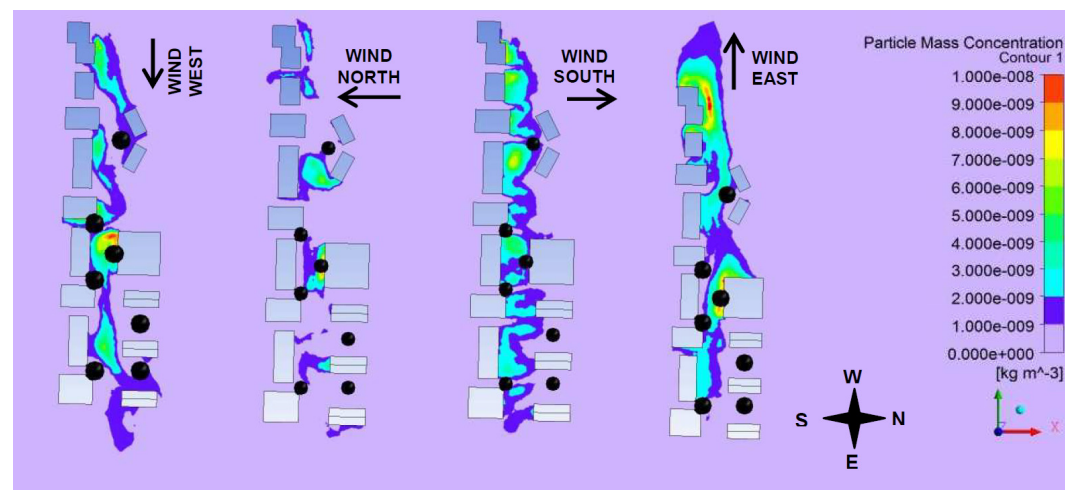

Figure 5: Contour plots of $\mathrm{PM}_{10}$ concentrations at $1.5 \mathrm{~m}$ level for disposition $\mathrm{C}(6 \mathrm{~m}$ gap) for the main four wind directions.

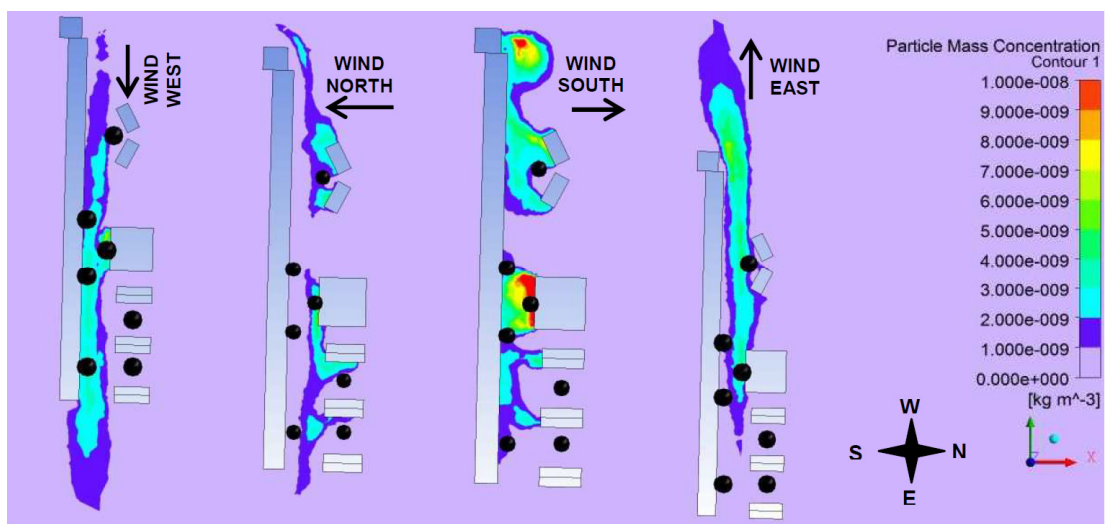

Figure 6: Contour plots of $\mathrm{PM}_{10}$ concentrations at $1.5 \mathrm{~m}$ level for disposition $\mathrm{D}$ (no gap same volume) for the main four wind directions. 
Table 2: $\quad \mathrm{PM}_{10}$ concentrations at $1.5 \mathrm{~m}$ high for disposition $\mathrm{B}$ (4m gap).

\begin{tabular}{|c|c|c|c|c|c|c|}
\hline Designation & Location & $\begin{array}{c}\text { PM }_{10} \text { Conc. } \\
\left(\mu \mathrm{g} / \mathrm{m}^{3}\right) \\
\text { West wind }\end{array}$ & $\begin{array}{c}\text { PM }_{10} \text { Conc. } \\
\left(\mu \mathrm{g} / \mathrm{m}^{3}\right) \\
\text { North wind }\end{array}$ & $\begin{array}{c}\text { PM }_{10} \text { Conc. } \\
\left(\mu \mathrm{g} / \mathrm{m}^{3}\right) \\
\text { South wind }\end{array}$ & $\begin{array}{c}\text { PM }_{10} \text { Conc. } \\
\left(\mu \mathrm{g} / \mathrm{m}^{3}\right) \\
\text { East wind }\end{array}$ & $\begin{array}{c}C W \\
(\mu \mathrm{g} / \mathrm{m} 3)\end{array}$ \\
\hline Point 1 & School & 22.3 & 20.8 & 22.7 & 22.2 & 21.8 \\
\hline Point 2 & Bingo & 25.7 & 23.2 & 21.8 & 27.6 & 24.1 \\
\hline Point 3 & Car park(border) & 20.0 & 20.0 & 20.0 & 20.0 & 20.0 \\
\hline Point 4 & Car park (middle) & 20.0 & 20.0 & 20.7 & 20.0 & 20.1 \\
\hline Point 5 & High building corner & 20.0 & 20.0 & 20.4 & 21.2 & 20.2 \\
\hline Point 6 & Residential building (east) & 21.0 & 20.1 & 23.9 & 20.7 & 21.2 \\
\hline Point 7 & Resid. building (west) & 23.3 & 20.0 & 21.2 & 20.0 & 21.6 \\
\hline Mean value & $1,5 \mathrm{~m}$ plane (all domain) & 20.5 & 20.3 & 20.6 & 20.8 & ---- \\
\hline $\mathrm{CW}$ & $1,5 \mathrm{~m}$ plane (all domain) & 20.2 & 20.0 & 20.1 & 20.0 & $\begin{array}{ll}--- \\
\end{array}$ \\
\hline
\end{tabular}

Table 3: $\quad \mathrm{PM}_{10}$ concentrations at $1.5 \mathrm{~m}$ high for disposition $\mathrm{C}(6 \mathrm{~m}$ gap).

\begin{tabular}{|c|c|c|c|c|c|c|}
\hline Designation & Location & $\begin{array}{c}\mathrm{PM}_{10} \text { Conc. } \\
\left(\mu \mathrm{g} / \mathrm{m}^{3}\right) \\
\text { West wind }\end{array}$ & $\begin{array}{c}\text { PM }_{10} \text { Conc. } \\
\left(\mu \mathrm{g} / \mathrm{m}^{3}\right) \\
\text { North wind } \\
\end{array}$ & $\begin{array}{c}\mathrm{PM}_{10} \text { Conc. } \\
\left(\mu \mathrm{g} / \mathrm{m}^{3}\right) \\
\text { South wind } \\
\end{array}$ & $\begin{array}{c}\mathrm{PM}_{10} \text { Conc. } \\
\left(\mu \mathrm{g} / \mathrm{m}^{3}\right) \\
\text { East wind } \\
\end{array}$ & $\begin{array}{c}C W \\
(\mu g / m 3)\end{array}$ \\
\hline Point 1 & School & 20.9 & 20.8 & 21.0 & 21.2 & 20.8 \\
\hline Point 2 & Bingo & 25.9 & 26.8 & 21.1 & 26.8 & 24.9 \\
\hline Point 3 & Car park(border) & 20.0 & 20.0 & 20.3 & 20.0 & 20.1 \\
\hline Point 4 & Car park (middle) & 20.4 & 20.0 & 20.5 & 20.0 & 20.3 \\
\hline Point 5 & High building corner & 20.0 & 20.0 & 20.1 & 20.1 & 20.1 \\
\hline Point 6 & Residential building (east) & 20.1 & 20.1 & 20.2 & 20.5 & 21.2 \\
\hline Point 7 & Resid. building (west) & 22.9 & 22.9 & 20.0 & 20.1 & 21.2 \\
\hline Mean value & $1,5 \mathrm{~m}$ plane (all domain) & 20.6 & 20.6 & 20.6 & 20.9 & ---- \\
\hline $\mathrm{CW}$ & $1,5 \mathrm{~m}$ plane (all domain) & 20.3 & 20.2 & 20.1 & 20.1 & ---- \\
\hline
\end{tabular}

Table 4: $\quad \mathrm{PM}_{10}$ concentrations at $1.5 \mathrm{~m}$ high for disposition $\mathrm{D}$ (no gap same volume).

\begin{tabular}{|c|c|c|c|c|c|c|}
\hline Designation & Location & $\begin{array}{c}\mathrm{PM}_{10} \text { Conc. } \\
\left(\mu \mathrm{g} / \mathrm{m}^{3}\right) \\
\text { West wind }\end{array}$ & $\begin{array}{c}\text { PM }_{10} \text { Conc. } \\
\left(\mu \mathrm{g} / \mathrm{m}^{3}\right) \\
\text { North wind }\end{array}$ & $\begin{array}{c}\mathrm{PM}_{10} \text { Conc. } \\
\left(\mu \mathrm{g} / \mathrm{m}^{3}\right) \\
\text { South wind }\end{array}$ & $\begin{array}{c}\mathrm{PM}_{10} \text { Conc. } \\
\left(\mu \mathrm{g} / \mathrm{m}^{3}\right) \\
\text { East wind }\end{array}$ & $\begin{array}{c}C W \\
(\mu \mathrm{g} / \mathrm{m} 3)\end{array}$ \\
\hline Point 1 & School & 20.0 & 21.3 & 21.5 & 22.0 & 20.8 \\
\hline Point 2 & Bingo & 24.1 & 22.8 & 30.7 & 23.0 & 24.7 \\
\hline Point 3 & Car park(border) & 20.0 & 20.1 & 20.0 & 20.0 & 20.0 \\
\hline Point 4 & Car park (middle) & 20.0 & 20.2 & 20.6 & 20.0 & 20.0 \\
\hline Point 5 & High building corner & 23.2 & 20.4 & 21.1 & 20.1 & 21.6 \\
\hline Point 6 & Residential building (east) & 23.3 & 20.0 & 21.9 & 20.4 & 21.8 \\
\hline Point 7 & Resid. building (west) & 22.2 & 22.2 & 21.4 & 20.7 & 21.3 \\
\hline Mean value & $1,5 \mathrm{~m}$ plane (all domain) & 20.3 & 20.4 & 20.8 & 20.6 & ---- \\
\hline $\mathrm{CW}$ & $1,5 \mathrm{~m}$ plane (all domain) & 20.1 & 20.1 & 20.2 & 20.0 & ---- \\
\hline
\end{tabular}

The results of figure 6 and table 4 shows the solution of considering the buildings with no gap but with the same volume represent a good solution that promotes good pollutant dispersion visible in the $1.5 \mathrm{~m}$ high mean concentration results obtained for this configuration.

\section{The short-term personal exposure results}

With the objective of studying the influence of the four different scenarios (A, B, $\mathrm{C}$ and $\mathrm{D}$ ) in short-term personal exposure to $\mathrm{PM}_{10}$, four pedestrian trajectories were considered for people crossing the street in the direction of the fluvial station. The four pedestrian trajectories are shown in figure 7 and the characterization is made in table 5. 


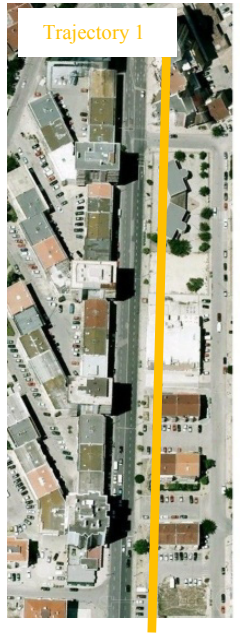

Figure 7: The four pedestrian trajectories considered.

Table 5: $\quad$ Characterization of the four pedestrian trajectories.

\begin{tabular}{|c|c|c|c|c|}
\hline $\begin{array}{c}\text { Pedestrian } \\
\text { trajectory }\end{array}$ & $\begin{array}{c}\text { Description } \\
\text { of trajectory }\end{array}$ & $\begin{array}{c}\text { Total walking } \\
\text { distance } \\
(\mathbf{m})\end{array}$ & $\begin{array}{c}\text { Walking mean } \\
\text { velocity } \\
(\mathbf{m} / \mathbf{s})\end{array}$ & $\begin{array}{c}\text { Total time } \\
(\mathbf{s})\end{array}$ \\
\hline 1 & Only north side & 300 & 1.0 & 300 \\
\hline 2 & Only south side & 300 & 1.0 & 300 \\
\hline 3 & North to south & 310 & 1.0 & 310 \\
\hline 4 & South to north & 310 & 1.0 & 310 \\
\hline
\end{tabular}

Short term personal exposure $\mathrm{E}(\mathrm{t})$ in a period of time $\mathrm{t}$ can be expressed as:

$$
E(\Delta t)=\int_{0}^{t} C(t) d t \cong C_{i} t_{i}
$$

where $\mathrm{C}(\mathrm{t})$ is the pollutant concentration in a particular time $\mathrm{t}$ in $\mu \mathrm{g} / \mathrm{m}^{3}, \mathrm{C}_{\mathrm{i}}$ is the discrete concentration in cellule $i$ in $\mu \mathrm{g} / \mathrm{m}^{3}$ and $t_{i}$ is time of expose in cellule $i$ in seconds.

In order to calculate the total exposure related with each of the pedestrian trajectories, the computational domain was discretized in a grid with 240 cellules and 279 nodes, each one correspondent to 10 s time walk trajectory. The shortterm personal exposure (E) was calculated in the nodes corresponding to the four pedestrian trajectories considered. This discrete grid is shown in figure 8 .

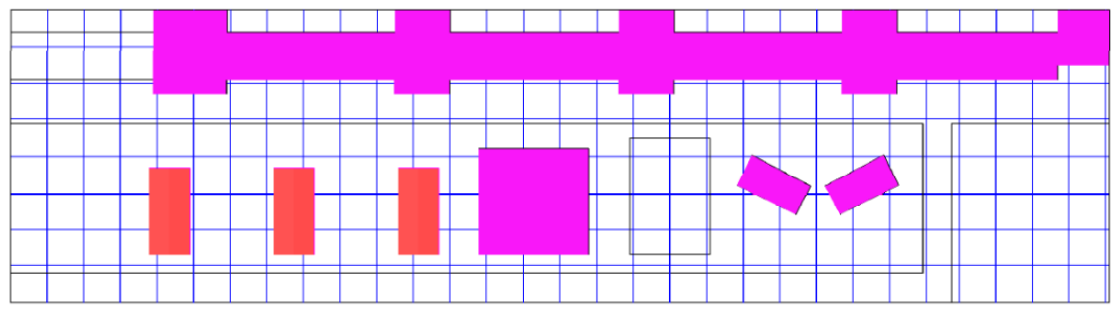

Figure 8: The discrete grid used in short-time exposure calculations. 
The results obtained to this short-time personal exposure to $\mathrm{PM}_{10}$ for the four scenarios (A, B, C and D), under the four main wind directions and to the four pedestrian trajectories considered (1, 2, 3 and 4) are shown in table 6.

Table 6: Short-term personal exposure to $\mathrm{PM}_{10}$ for the four trajectories considered.

\begin{tabular}{|c|c|c|c|c|c|c|c|c|c|c|c|c|c|c|c|c|}
\hline \multirow{2}{*}{$\begin{array}{c}\text { Pedes } \\
\text { trian } \\
\text { trajec } \\
\text { tory }\end{array}$} & \multicolumn{4}{|c|}{ Scenario A } & \multicolumn{4}{|c|}{ Scenario B } & \multicolumn{4}{|c|}{ Scenario C } & \multicolumn{4}{|c|}{ Scenario D } \\
\hline & $\begin{array}{c}\text { W } \\
\text { wind }\end{array}$ & $\underset{\text { wind }}{\mathrm{N}}$ & $\begin{array}{c}\mathrm{S} \\
\text { win } \\
\mathrm{d}\end{array}$ & $\begin{array}{c}\mathrm{E} \\
\text { wind }\end{array}$ & $\begin{array}{c}\text { W } \\
\text { wind }\end{array}$ & $\begin{array}{c}\mathrm{N} \\
\text { wind }\end{array}$ & $\begin{array}{c}\mathrm{S} \\
\text { win } \\
\mathrm{d}\end{array}$ & $\begin{array}{c}E \\
\text { wind }\end{array}$ & $\begin{array}{c}\text { W } \\
\text { wind }\end{array}$ & $\begin{array}{c}\mathrm{N} \\
\text { wind }\end{array}$ & $\begin{array}{c}\mathrm{S} \\
\text { win } \\
\mathrm{d}\end{array}$ & $\underset{\text { wind }}{E}$ & $\begin{array}{c}\mathrm{W} \\
\text { wind }\end{array}$ & $\begin{array}{c}\mathrm{N} \\
\text { wind }\end{array}$ & $\begin{array}{c}\mathrm{S} \\
\text { win } \\
\mathrm{d}\end{array}$ & $\begin{array}{c}\text { E } \\
\text { wi } \\
\text { nd }\end{array}$ \\
\hline 1 & 6059 & 6033 & $\begin{array}{c}611 \\
9\end{array}$ & 6189 & 6045 & 6021 & $\begin{array}{c}600 \\
2\end{array}$ & 6059 & 6020 & 6019 & $\begin{array}{c}601 \\
3 \\
\end{array}$ & 6059 & 6009 & 6000 & $\begin{array}{c}604 \\
5\end{array}$ & $\begin{array}{l}60 \\
07 \\
\end{array}$ \\
\hline 2 & 6066 & 6036 & $\begin{array}{c}613 \\
8\end{array}$ & 6175 & 6049 & 6016 & $\begin{array}{c}601 \\
5\end{array}$ & 6068 & 6045 & 6012 & $\begin{array}{c}601 \\
1\end{array}$ & 6064 & 6057 & 6030 & $\begin{array}{c}608 \\
9\end{array}$ & $\begin{array}{l}60 \\
45 \\
\end{array}$ \\
\hline 3 & 6274 & 6244 & $\begin{array}{c}634 \\
1\end{array}$ & 6370 & 6185 & 6125 & $\begin{array}{c}621 \\
3 \\
\end{array}$ & 6279 & 6183 & 6121 & $\begin{array}{c}620 \\
9 \\
\end{array}$ & 6271 & 6211 & 6215 & $\begin{array}{c}622 \\
0\end{array}$ & $\begin{array}{l}62 \\
27 \\
\end{array}$ \\
\hline 4 & 6263 & 6228 & $\begin{array}{c}633 \\
7\end{array}$ & 6361 & 6172 & 6115 & $\begin{array}{c}620 \\
1\end{array}$ & 6264 & 6170 & 6114 & $\begin{array}{c}626 \\
0\end{array}$ & 6265 & 6248 & 6248 & $\begin{array}{c}622 \\
3\end{array}$ & $\begin{array}{l}62 \\
29\end{array}$ \\
\hline
\end{tabular}

All values in $\mu \mathrm{g} . \mathrm{s} / \mathrm{m}^{3}$

By the analysis of the results it is possible to verify that the lowest value for short-term personal exposure is obtained for pedestrian trajectory 1 in scenario D under north wind conditions. The highest value for short-term exposure is obtained for pedestrian trajectory 3 in scenario D under east wind conditions. It is visible that pedestrian trajectories 3 and 4 are always worse than trajectories 1 and 2. That is related with the fact that trajectories 3 and 4 correspond to crossing the street in an area were the $\mathrm{PM}_{10}$ concentration is higher.

\section{Conclusions}

CFD software Ansys Fluent 12 was used to simulate and study the particle concentrations $\left(\mathrm{PM}_{10}\right)$ and correspondent short-term personal exposure in a busy street with high road traffic, in Barreiro city in Portugal. Four different configurations for the street, considering various building dimensions and gaps between buildings were simulated. Looking to the results obtained, it is possible to conclude that the street configuration and building geometry have an important influence in the results for $\mathrm{PM}_{10}$ concentration in the street. The results also show that $\mathrm{PM}_{10}$ concentration is strongly dependent on the predominant wind direction. The results for $\mathrm{PM}_{10}$ mean concentration at $1.5 \mathrm{~m}$ high, for west wind and east wind directions show that better concentrations levels are obtained with configuration D (no gaps between buildings but same volume) because this geometry promotes the dispersion of pollutants as the wind is oriented with buildings. For north wind and south wind directions, configuration B is the one that results in lower concentrations. For these wind directions there are no visible improvements in having higher gaps $(6 \mathrm{~m})$ between buildings instead of $4 \mathrm{~m}$ gaps. So the best configuration for this street considering the wind direction and the frequencies of occurrence is configuration $\mathrm{B}$. For theses $\mathrm{PM}_{10}$ obtained concentrations, the level of short-term personal exposure in dependent of the pedestrian trajectory considered in the street. The best short-term exposure 
values are obtained for scenario D (when buildings have the same volume) for trajectory 1 (walking only on the south side of street) and under North wind conditions. The worst short-term exposure is obtained for pedestrian trajectory 3 in scenario A under East wind conditions. We can also conclude that pedestrian trajectories 3 and 4 (crossing the street in the centre of street) are always worst for personal exposure than trajectories 1 and 2 .

\section{References}

[1] Martins, A., Cerqueira M., Ferreira F., Borrego C., Amorim J. H. (2009), "Lisbon air quality: evaluating traffic hot-spots", International Journal Environment and Pollution, Volume 39, 374, pp. 306-320.

[2] Amorim, J. H., Lopes, M., Borrego, C., Tavares, R., Miranda, A. I., (2010) "Air quality modelling as a tool for sustainable urban traffic management", Ecology and the Environment, volume 136.

[3] Kumar, P., Ketzel M., Vardoulakis S., Pirjola L., Britter R., (2011), "Dynamics and dispersion modeling of nanoparticles from road traffic in the urban atmospheric environment - a review”, Journal of Aerosol Science, 42, pp. 580-603.

[4] Garcia, J., Coelho, L., Gouveia C., Cerdeira, R., Louro, C., Ferreira, T., Baptista M. (2010), "Analyses of human exposure to urban air quality in a children population", International Journal of Environment and Pollution, 1/2/3, 40:pp94-108.

[5] Di Sabatino, S. Buccolieri, Pulvirenti B, Britter (2008), "Flow and Pollutant Dispersion in Street Canyons using FLUENT and ADMS-Urban", Environ Model Assess, 13:pp. 369-381.

[6] Awasthi S., Chaudhry, K. K., (2009) "Numerical simulation and wind tunnel studies of pollution dispersion in an isolated street Canyon", International Journal of Environment and Waste Management, Volume 4, 1-2, 243-255.

[7] FLUENT (2009) Manual, Chapter 4. Turbulence ANSYS, Inc. January.

[8] Garcia, J., Cerdeira, R., Tavares, N, Coelho, L. M. R., Kumar, P. (2011), "Comparative study of measured and modeled PM10 concentrations in different building configurations of an urban street canyon", Atmospheric Environment journal (under review). 